\title{
Mass mortalities associated with viral nervous necrosis (VNN) disease in two species of hatchery-reared grouper, Epinephelus fuscogutatus and Epinephelus akaara (Temminck \& Schlegel)
}

\author{
S C Chi ${ }^{1}$, C F Lo ${ }^{1}$, G H Kou ${ }^{1}$, P S Chang ${ }^{2}$, S E Peng ${ }^{1}$ \& S N Chen ${ }^{1}$ \\ 1 Department of Zoology, National Taiwan University, Taipei, Taiwan, ROC \\ 2 National Kao-Hsiung Institute of Marine Technology, Kao Hsiung, Taiwan, ROC
}

\begin{abstract}
Mass mortalities of hatchery-reared juvenile groupers have occurred in southern Taiwan. The diseased fish swam in a darting, corkscrew fashion. Light microscopy revealed vacuolation in the brain tissue. Electron microscopy showed numerous nonenveloped, cytoplasmic viral particles (20-25 nm in diameter) in the brain cells, and many virions were enclosed in the membrane-bound organelles of the cells. Two structural proteins of the purified grouper virus, with molecular weights of 44 and $43 \mathrm{kDa}$, were revealed by SDS-PAGE. Moreover, the results of RT-PCR and nested PCR diagnosis using primers specific to the T2 and T4 target segments of striped jack nervous necrosis virus (SJNNV) RNA2 genes suggest that this virus is a fish nodavirus, and is designated as GNNV 9410 strain (grouper nervous necrosis virus strain 9410). This is the first case report of viral nervous necrosis among marine fish in Taiwan.
\end{abstract}

\section{Introduction}

With the rapid growth of marine aquaculture in Taiwan, new kinds of infectious viral diseases are emerging and are causing serious losses. Grouper has a high economic value in Taiwan, but during recent years, many grouper hatcheries have experienced outbreaks of an unknown disease resulting in mass mortalities. The diseased grouper

Correspondence: Dr Shau-Chi Chi, Department of Zoology, National Taiwan University, Taipei, Taiwan, ROC juveniles showed unusual swimming behaviour, such as whirling near the surface of the water, abrupt swimming in a corkscrew fashion, sinking to the bottom and then floating to the water surface.

A new viral disease named viral nervous necrosis (VNN) has been reported among hatcheryreared Japanese parrotfish, Oplegnathus fasciatus (Temminck \& Schlegel), (Yoshikoshi \& Inoue 1990), barramundi, Lates calcarifer Bloch, (Glazebrook, Haesman \& de Beer 1990; Renault, Haffner, Baudin Laurencin, Breuil \& Bonami 1991; Munday, Langdon, Hyatt \& Humphrey 1992), sea bass, Dicentrarchus labrax (L.), (Breuil, Bonami, Pepin \& Pichot 1991), turbot, Scophthalmus maximus (L.), (Bloch, Gravningen \& Larsen 1991), redspotted grouper, Epinephelus akaara (Temminck \& Schlegel), (Mori, Nakai, Nagahara, Muroga, Mckuchi \& Kanno 1991), and striped jack, Pseudocaranx dentex Bloch \& Schneider, (Mori, Nakai, Muroga, Arimoto, Mushiakc \& Furusawa 1992) from many parts of the world. Viral nervous necrosis disease occurs during larval and juvenile stages of marine fish, and is characterized by high mortality and accompanying vacuolation of the nerve tissues. Unenveloped spherical virus particles (25-34 nm) were found in affected fish, but so far, no cell lines are available for isolating these viruses (Yoshikoshi \& Inoue 1990; Breuil et al. 1991; Mori et al. 1991; Munday et al. 1992).

The causative agent of VNN from diseased larvae of striped jack was successfully purified and identified as a member of the family Nodaviridae according to its nucleic acid and protein properties,
(C) 1997

Blackwell Science Ltd 
and the virus was designated SJNNV, an acronym for striped jack nervous necrosis virus (Mori et al. 1992). Recently, a polymerase chain reaction (PCR) method was developed to amplify a portion of the coat protein gene (RNA2) of SJNNV (Nishizawa, Mori, Nakai, Furusawa \& Muroga 1994).

In the present paper, the virion causing high mortalities of banded grouper juveniles was studied and identified using both light and electron microscopy, the PCR amplification method described by Nishizawa et al. (1994), and SDSPAGE of purified virions. The results indicated that GNNV strain 9410, found in moribund banded grouper juveniles, is an example of fish nervous necrosis virus, also known as fish encephalomyelitis virus, and is a member of the Nodaviridae. This is the first report of VNN in marine fish in Taiwan.

\section{Materials and methods}

Fish samples

Diseased grouper juveniles $(2-3 \mathrm{~cm}$ in total length) were taken from the Mito hatchery farm in Taiwan in October 1994. At this particular farm, the eggs of red spotted grouper and the black spotted grouper were mixed together, and hatched in the same tank. Juveniles of the two grouper species were also reared together in the same pond. The fish were cultured at a density of 10000 fish $\mathrm{m}^{3}$ at $26-30^{\circ} \mathrm{C}$. Mortalities were nearly $95 \%$. Live samples were fixed for observation by light and electron microscopy, and the rest were frozen at $-20^{\circ} \mathrm{C}$.

It is very difficult to distinguish between the black spotted grouper and the red spotted grouper at $2-3 \mathrm{~cm}$ body length; therefore, the specific identity of the fish from each sample examined in this study was not determined.

\section{Histopathological examination}

Fish were fixed in $10 \%$ buffered formalin and embedded in paraffin wax. Sections of $5 \mu \mathrm{m}$ were then stained with haematoxylin and eosin (H\&E). For electron microscopy, fish were fixed in $2.5 \%$ glutaraldehyde in $0.1 \mathrm{M}$ phosphate buffer at $\mathrm{pH}$ 7.4 and post-fixed in $1 \%$ osmium tetroxide. Ultrathin sections were stained with uranyl acetatelead citrate and examined under a Hitachi $\mathrm{H}$ 600A electron microscope.

\section{Extraction of total nucleic acids from diseased} fish

For rapid tissue preparation, the deproteinized viral RNA was prepared according to the method described by Strauss (1994). Briefly, each fish sample was frozen in liquid nitrogen and homogenized. The homogenized tissue $(100 \mathrm{mg})$ was then added to $2.4 \mathrm{ml}$ of digestion buffer $(100 \mathrm{~mm} \mathrm{NaCl}, 10 \mathrm{~mm}$ Tris- $\mathrm{HCl}$ at $\mathrm{pH} 8,25$ $\mathrm{mM}$ EDTA at $\mathrm{pH} 8,0.5 \%$ sodium dodecyl sulphate and $0.1 \mathrm{mg} \mathrm{ml}^{-1}$ proteinase $\mathrm{K}$ ) and incubated at $65^{\circ} \mathrm{C}$ for $3 \mathrm{~h}$. The digestion mixture was then extracted using the phenol/chloroform/ isoamyl alcohol method, precipitated with ethanol, and resuspended in diethyl pyrocarbonate water. The quality and the quantity of the purified nucleic acids were determined by using a Hitachi spectrophotometer U-200.

\section{Primers for PCR amplification}

Three primers for carrying out PCR amplification of the extracted nucleic acids were synthesized by the DNAFax Company, the primer sequences of these primers being based on those of Nishizawa et al. (1994). The sequence of each primer is as follows: (forward primer 1, F1) 5'-GGATTTGGACGTGCGACCAA-3'; (forward primer 2, F2) 5'-CGTGTCAGTCATGTGTCGCT-3'; and (reverse primer 3, R3) 3'-AGAAGTGGGCACAACTGAGC-5'. The target region expected to be amplified from F1 to R3 is T2 (875 bp) and the target region for F2 to R3 is T4 (426 bp).

\section{Reverse transcription and PCR amplification}

For reverse transcription, the nucleic acids extracted by the above procedure were pre-heated at $95^{\circ} \mathrm{C}$ for $5 \mathrm{~min}$, and then incubated at $42^{\circ} \mathrm{C}$ for $1 \mathrm{~h}$ in $30 \mu \mathrm{l}$ of reverse transcription buffer mixture consisting of $2 \mu \mathrm{g}$ of nucleic acids, $3.3 \mu \mathrm{M}$ of random primer, $0.5 \mathrm{mM}$ of each $\mathrm{dNTP}, 50 \mathrm{mM}$ Tris- $\mathrm{HCl}$ at $\mathrm{pH} 8.3,75 \mathrm{mM} \mathrm{KCl,} 3 \mathrm{mM} \mathrm{MgCl}_{2}$, $0.01 \mathrm{M}$ DTT, $1.3 \mu \mathrm{M}$ RNAsin and $400 \mathrm{U}$ M-MLV reverse transcriptase (BRL). Following cDNA synthesis, cDNA was added to the PCR mixture to a final volume of $100 \mu \mathrm{l}$ containing $0.5 \mu \mathrm{g}$ forward primer, $0.5 \mu \mathrm{g}$ reverse primer, $0.2 \mathrm{mM}$ of each dNTP, $50 \mathrm{~mm} \mathrm{KCl}, 10 \mathrm{~mm}$ Tris- $\mathrm{HCl}$ at $\mathrm{pH} 9.0,0.1 \%$ Triton X-100, $2 \mathrm{~mm}$ $\mathrm{MgCl}_{2}$ and $2.5 \mathrm{U}$ Taq DNA polymerase (Promega) 
to a final volume of $50 \mu \mathrm{l}$. The mixture was then incubated in an automatic thermal cycler (PTC-100 thermal cycler; MJ Research Inc., USA). The primer set used in this amplification was F1-R3. The expected target region was T2. The amplification was performed for one cycle at $94^{\circ} \mathrm{C}$ for $3 \mathrm{~min}$; 40 cycles at $94^{\circ} \mathrm{C}$ for $1 \mathrm{~min}$, $55^{\circ} \mathrm{C}$ for $1 \mathrm{~min}$ and $72^{\circ} \mathrm{C}$ for $5 \mathrm{~min}$; and one cycle at $72^{\circ} \mathrm{C}$ for $15 \mathrm{~min}$. After amplification, the PCR products were analysed on $1.5 \%$ agarose gel.

\section{Nested PCR amplification}

Nested PCR amplification was performed immediately using the RT-PCR products as template. An F2-R3 primer set was used in this amplification. The target region was T4 $(426 \mathrm{bp})$. The amplification conditions were as for RT-PCR. The amplified sequences were analysed on a $2 \%$ agarose gel.

\section{Purification of the virus}

The virus was isolated and purified according to the method described by Mori et al. (1992). The purified virus was negatively stained by $1 \%$ phosphotungstic acid and observed under TEM.

\section{Electrophoresis of the purified virus}

Purified virus was analysed by $12 \%$ SDS-PAGE and stained by Coomassie blue. The gel was then screened by a laser-based imaging densitometer (Molecular Dynamics, PDSI-PC, USA) and the molecular weights of viral proteins were determined by the image fragment analysis program of the PDSI-PC.

\section{Results}

\section{Clinical signs and gross pathology}

The first signs of an outbreak of this disease were behavioural; the fish lost their equilibrium and swam in a corkscrew fashion. Affected fish were generally lethargic, and some floated on their sides on the water surface, but responded to alarm or physical stimulation with a brief burst of erratic swimming. Sometimes the fish sank to the bottom and then floated to the surface again.

A few diseased fish were darker than normal.
The livers of diseased fish were pale, the digestive tracts were devoid of food, the intestines filled with a greenish to brownish fluid and the spleens were red-spotted. Affected fish showed no signs of bacterial infection or parasitism.

\section{Histopathology}

Under the light microscope, the brain of affected fish showed conspicuous vacuolation (Fig. 1). The extent of the lesions varied considerably from fish to fish. Ultrathin sections showed that numerous virions completely or partially filled the membranebound organelles in the cytoplasm of virus-infected brain cells (Fig. 2). These virions were nonenveloped, homogeneous, spherical to icosahedral particles with diameter of 20-25 nm, and were usually arranged in paracrystalline arrays, as shown in Fig. 3. Some membrane-bound organelles had a single layer of viral particles on the inner surface of the membrane (Fig. 4). In some viruscontaining organelles, the membrane structures degenerated and four to five layers of viral particles were assembled at the site of pre-existing membranes (Fig. 5). Large vacuoles were always seen in the heavily virus-infected cells (Fig. 6).

\section{PCR amplification}

Deproteinized nucleic acids extracted from three different diseased fish were analysed by RT-PCR and nested PCR amplification using primers specific to SJNNV RNA2 gene. The results of RT-PCR in the presence of the F1-R3 primer set are shown in Fig. 7. The three separate nucleic acid preparations consistently produced a major band with a size similar to that of the $\mathrm{T} 2$ region (875 bp) of SJNNV RNA2. Figure 8 shows the results of the nested PCR amplification using an internal primer set (F2-R3) for the T4 region. The $400 \mathrm{bp}$ size of the nested PCR product is similar to that of the T4 region of the SJNNV RNA2 gene. Taken together, these results indicate that the viral agent in the juvenile groupers is closely related to the SJNNV, which has been identified as belonging to the Nodaviridae family (Mori et al. 1992).

\section{Virus purification}

The purified virus appeared icosahedral in morphology and the average diameter of 30 viral particles was $25 \mathrm{~nm}$ (Fig. 9). 


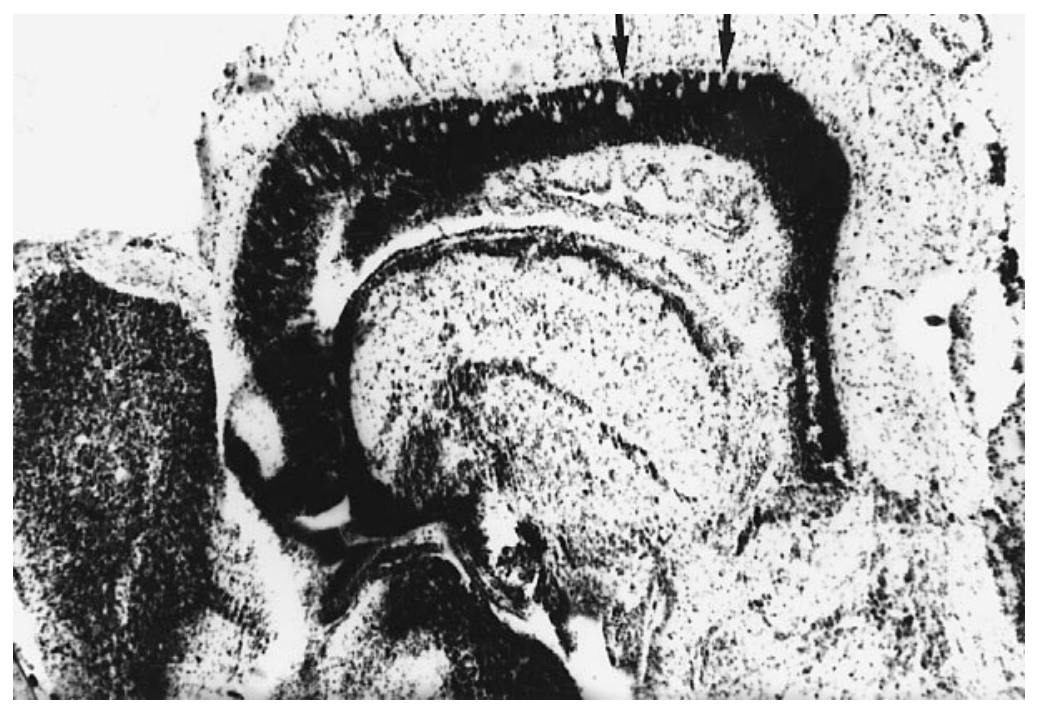

Figure 1 Light micrograph demonstrating vacuolation (arrows) in the mid-brain of diseased juvenile grouper (H\&E).

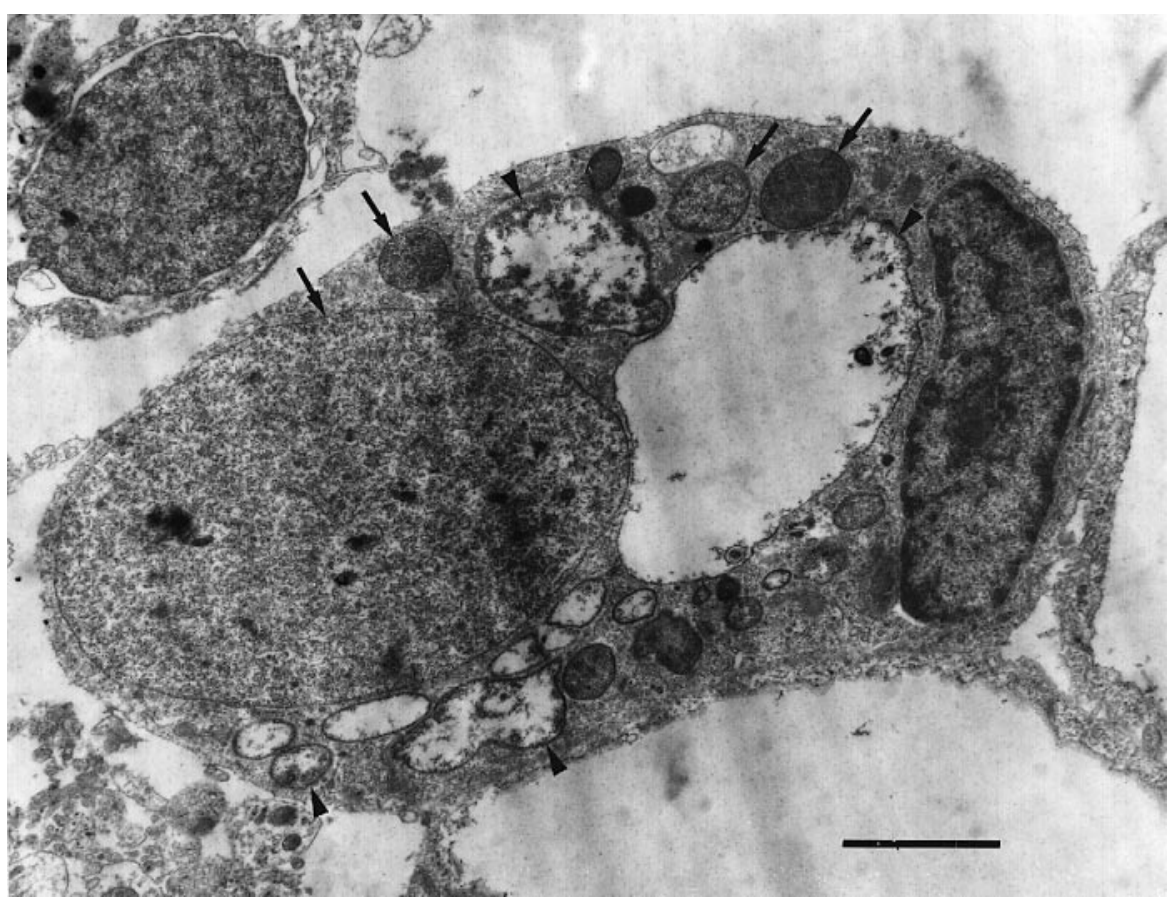

Figure 2 Electron micrograph showing the GNNV-infected cells with different sizes of membrane-bound organelles completely filled (arrows) or partially filled (arrowheads) with viral particles (bar $=2 \mu \mathrm{m}$ ).

Electrophoresis of viral proteins

Purified virus had structural proteins with molecular weights of 44 and $43 \mathrm{kDa}$ (Fig. 10). The molecular weight was calculated by laser densitometry. The molecular weights of the viral structural proteins of grouper virus are a little higher than those of SJNNV which are 42 and $40 \mathrm{kDa}$ (Mori et al. 1992).

\section{Discussion}

Viral nervous necrosis (VNN) in marine fish, also known as fish encephalomyelitis, has been reported
(C) 1997

Blackwell Science Ltd 


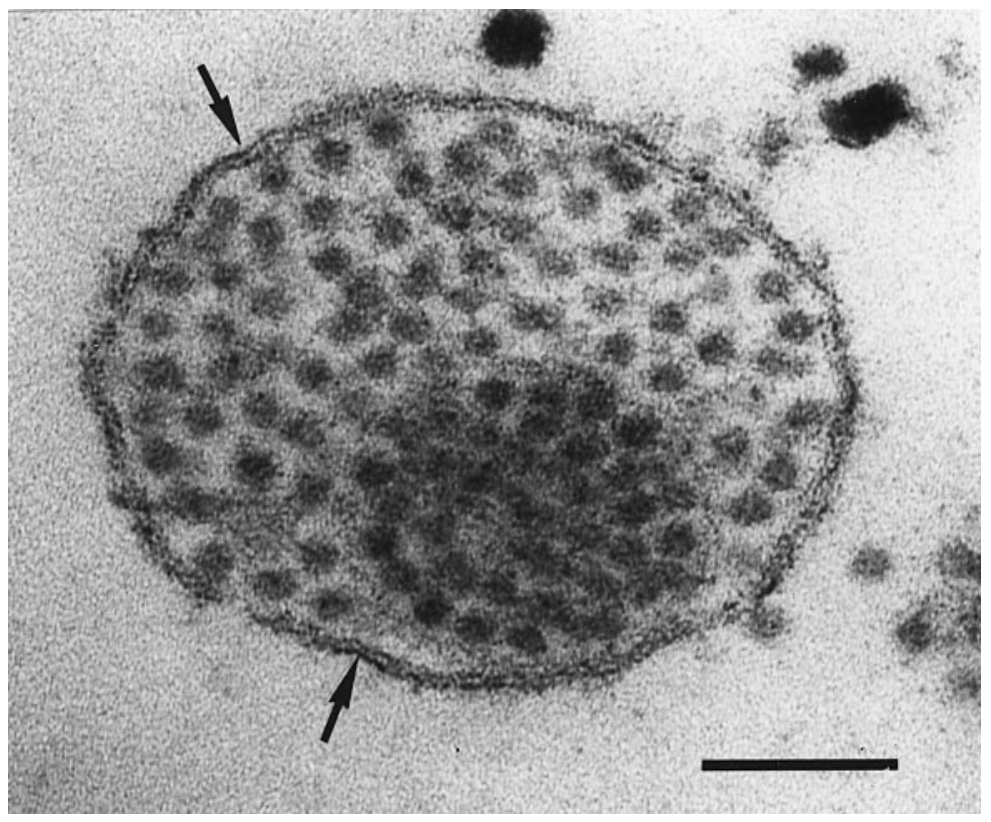

Figure 3 Electron micrograph showing non-enveloped, spherical viral particles packed in paracrystalline arrays in membrane-bound organelles. Arrows indicate the lipid bilayer structure of the membrane $(\mathrm{bar}=100 \mathrm{~nm})$.

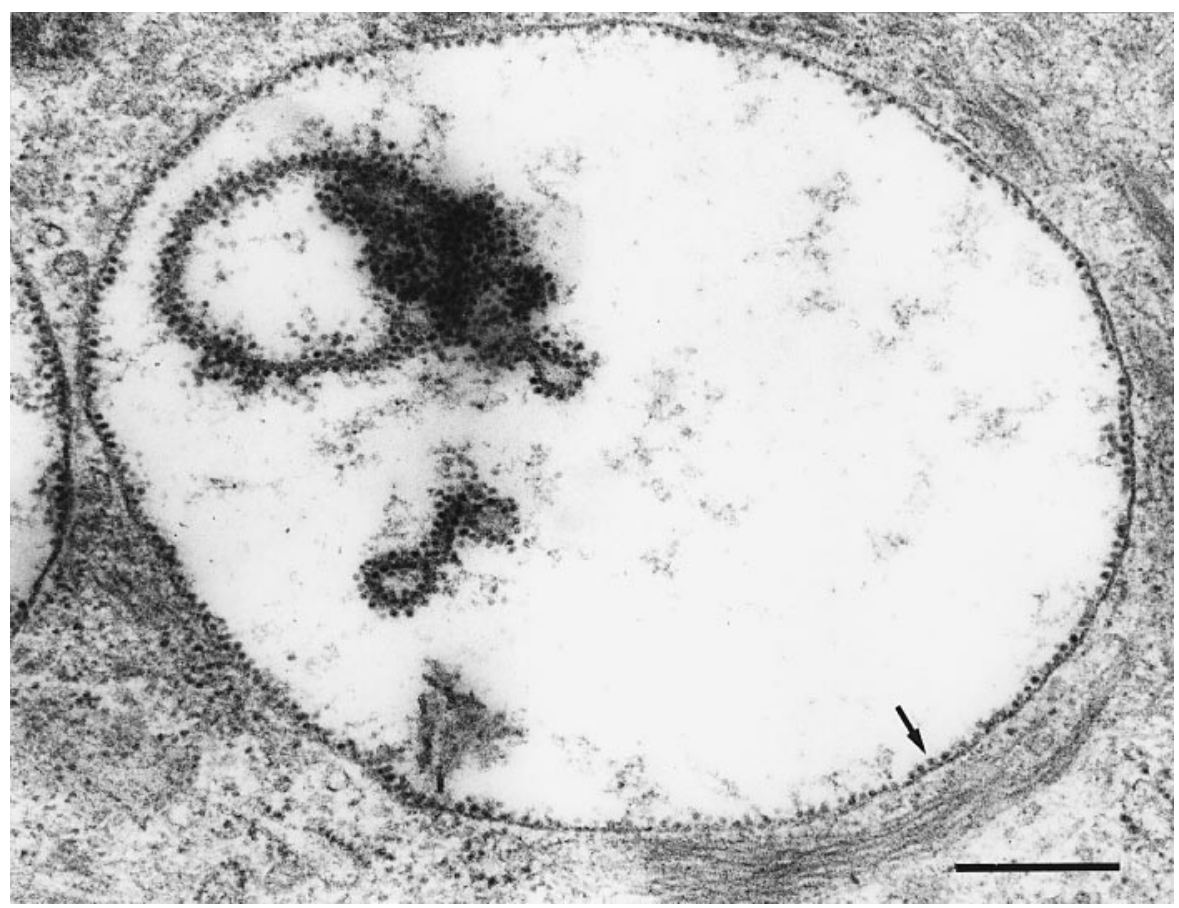

Figure 4 Electron micrograph showing a single layer of virions (arrow) lining the inner surface of a membrane-bound organelle in an infected brain cell $($ bar $=400 \mathrm{~nm})$.

in a number of countries: Malaysia (Awang 1987), Japan (Yoshikoshi \& Inoue 1990; Mori et al. 1991), North Australia (Glazebrook et al. 1990; Munday et al. 1992), France (Breuil et al. 1991; Renault et al. 1991) and Norway (Bloch et al. 1991). In this paper, we reported the existence of a viral strain,
(C) 1997

Blackwell Science Ltd 


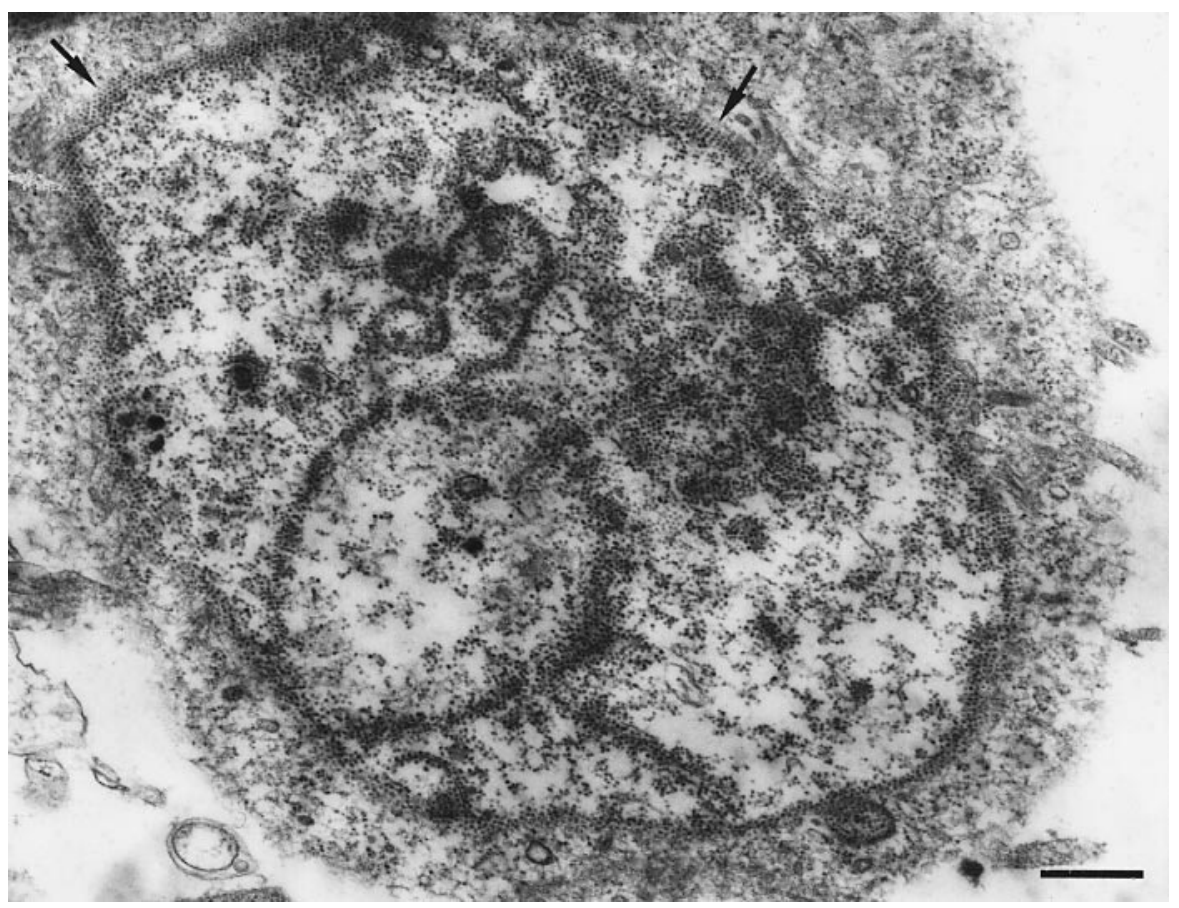

Figure 5 Electron micrograph showing degeneration of membrane structures of cellular organelles. Arrows indicate four to five layers of viral particles $(\mathrm{bar}=500 \mathrm{~nm})$.

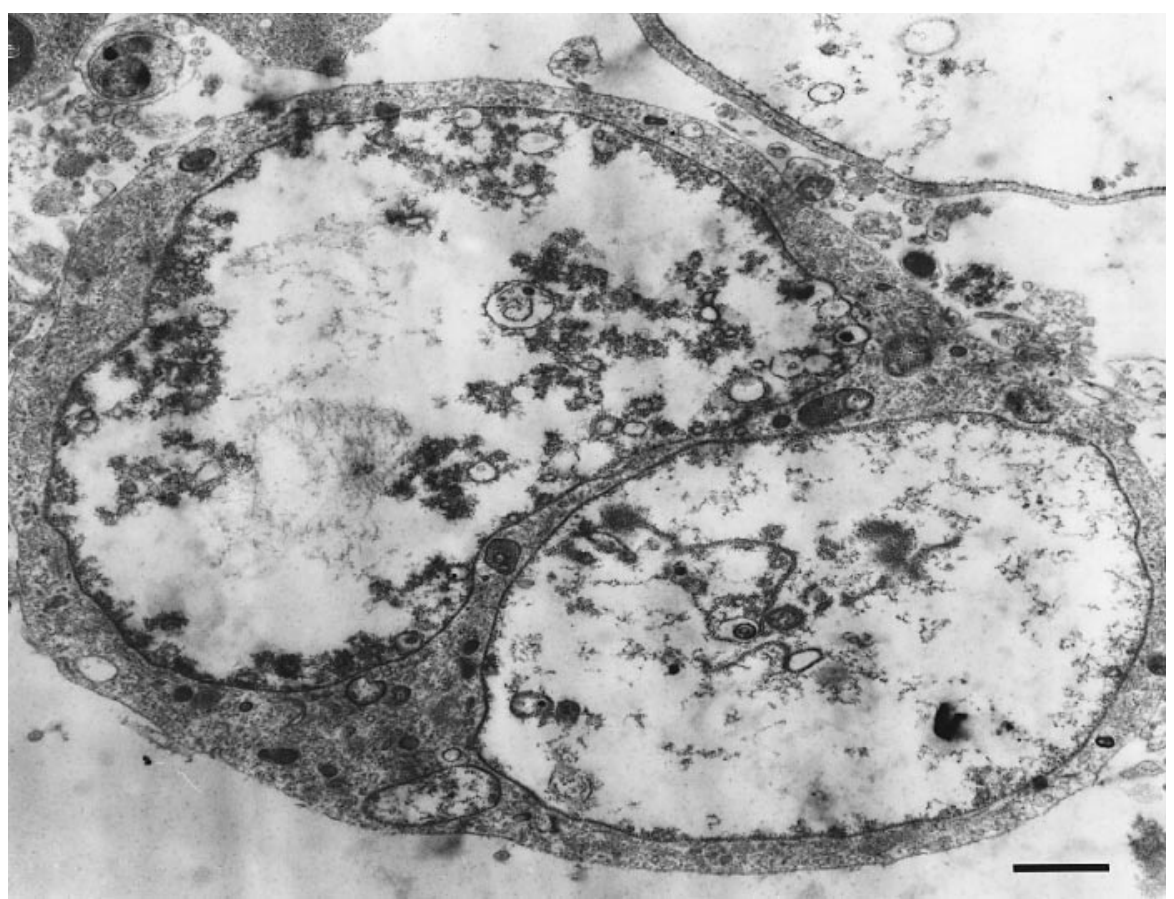

Figure 6 Electron micrograph showing heavily virus-infected brain cell with large vacuoles in the cytoplasm $(\mathrm{bar}=1 \mu \mathrm{m})$. 


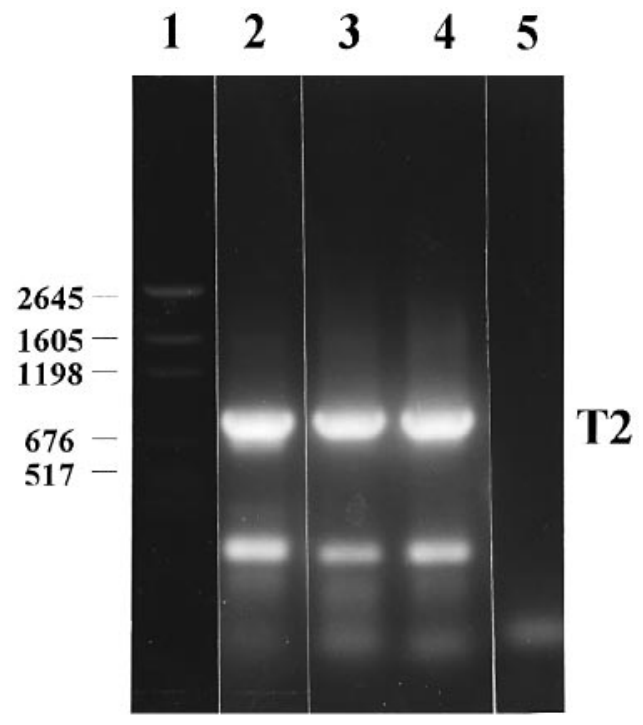

Figure 7 Agarose gel electrophoresis of the products by RT-PCR amplification using primers specific to the T2 target region of SJNNV RNA2 and the nucleic acids extracted from three diseased juvenile groupers as templates. An F1-F3 primer set specific for the T2 target region was used in RT-PCR amplification. The expected size of the T2 region is $875 \mathrm{bp}$. Lane 1 is pGEM marker; lanes $2-4$ show the PCR product from nucleic acids extracted from the three different fish; and lane 5 shows a template-free control reaction.

named GNNV strain 9410, found in the CNS of juvenile grouper reared at the Mito hatchery in southern Taiwan, and determined its classification using RT-PCR and nested PCR amplification techniques with SJNNV RNA-2 specific primer sets, and the structural protein profile analysis of purified virus by electrophoresis. This is the first record of viral nervous necrosis among hatcheryreared grouper in Taiwan.

Under light microscopy, many vacuoles were found in the brain tissue of the diseased fish, especially in the mesencephalon. With the electron microscope, viral particles were found only in the cytoplasm of the brain cells in close association with intracytoplasmic cell membranes. Mature viral particles were packed inside the endoplasmic reticulum cisternae, resulting in membrane-bound organelles filled with virus particles, and then released into the cytoplasm by destruction of the organelle membrane. High concentrations of cytoplasmic viruses gradually displace the cellular organelles. These observations suggest that the viral agent in the juvenile grouper is an RNA virus and that intracellular membranes support its replication.

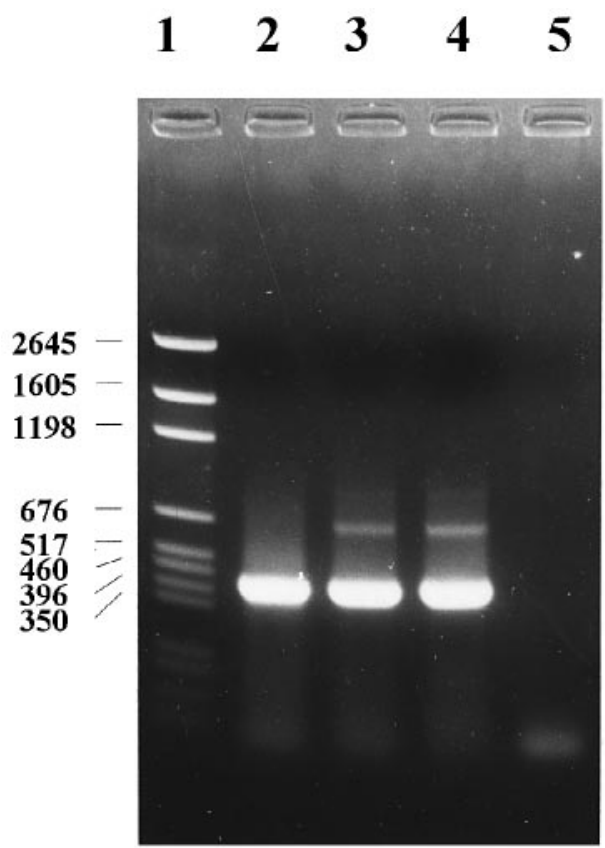

Figure 8 The products in the nested PCR amplification using the F2-R3 primer set specific to the T4 target region of SJNNV RNA2 and the product of RT-PCR as DNA templates. Lane 1 shows pGEM marker; lanes 2-4 show PCR products of three different diseased fish; lane 5 shows a template-free control reaction.

It is believed that GNNV is the main cause of mortality among juvenile grouper because of the corkscrew swimming behaviour displayed by affected fish, the fact that neither parasites nor pathogenic bacteria were detected in moribund fish, and the similarity of histo- and cytopathological signs to the characteristics of VNN disease among marine fish previously described (Yoshikoshi \& Inoue 1990; Renault et al. 1991; Mori et al. 1992).

Nervous necrosis virus was originally tentatively identified as a Picornavirus based on its ability to replicate in the cytoplasm, its association with membrane structures, its size $(25-30 \mathrm{~nm})$ and its RNA content (Glazebrook et al. 1990). Later, Mori et al. (1992) clearly identified the VNN virus isolated from the striped jack as a member of the family Nodaviridae because SJNNV has two singlestranded, positive-sense RNAs with molecular weights of $1.0 \times 10^{6} \mathrm{Da}$ (RNA1) and $0.49 \times 10^{6} \mathrm{Da}$ (RNA2), and the RNAs of SJNNV do not have a poly(A) tail. Also, RNA1 directs the synthesis of 1a protein $(100 \mathrm{kDa})$, and RNA2 directs the synthesis of $2 \mathrm{a}$ protein $(42 \mathrm{kDa})$, which is the coat protein of the virus (Mori et al. 1992).
(C) 1997

Blackwell Science Ltd 


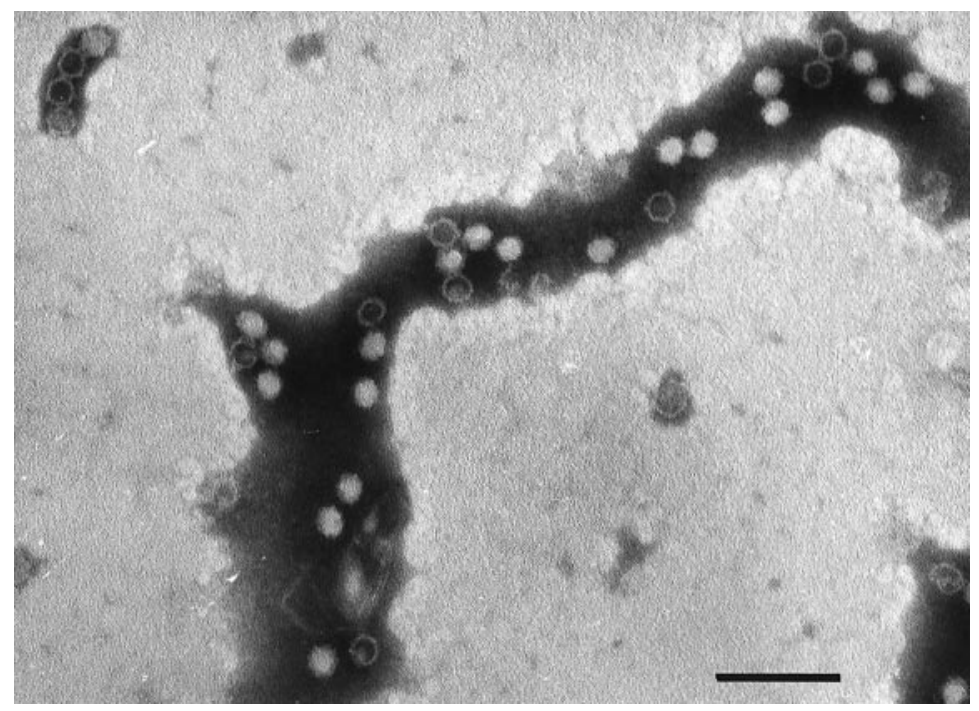

Figure 9 The morphology of the purified virus isolated from diseased grouper juveniles $(\mathrm{bar}=100 \mathrm{~nm})$.

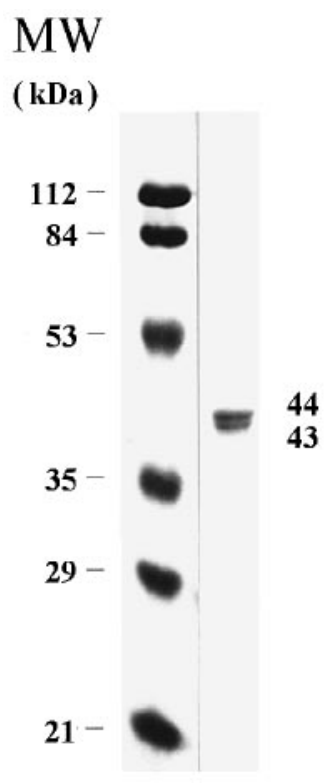

Figure 10 The structural proteins of the purified viruses from diseased grouper analysed by $12 \%$ SDS-PAGE.

Five primer sets specific for the SJNNV RNA2 target regions T1, T2, T3, T4 and T5 were designed by Nishizawa et al. (1994). Among these five, the T4 region was recommended as the most suitable target region for a PCR amplification of the coat protein gene of fish nodavirus, and the T4 target region has been detected in PCR products of VNN viruses from four other kinds of marine fish
(Nishizawa, Mori, Nakai, Furusawa \& Muroga 1995).

In this study, we used two SJNNV RNA-2 specific primer sets, F1-R3 and F2-R3, in a PCR amplification test designed to identify suspected viral nucleic acids in infected grouper tissue. A major band similar in size to the T2 region $(875$ bp) in the RT-PCR, and an obvious band similar in size to the T4 region ( $426 \mathrm{bp}$ ) in the nested PCR test, were detected. These results indicate that the virus from banded groupers is closely related to SJNNV. In addition, the purified viral particles were non-enveloped, spherical to icosahedral in shape, 20-25 $\mathrm{nm}$ in diameter, and the molecular weights of structural proteins were 44 and $43 \mathrm{kDa}$, which were similar to SJNNV (Mori et al. 1992) and other insect nodaviruses (Glazon \& Charpentier 1991). These results, together with the clinical signs of the diseased fish and the light and electron microscope observations, suggest that the virus isolated from the grouper juveniles, designated as GNNV 9410 strain, is an aquatic nodavirus. Comparison of the gene sequences of the GNNV 9410 strain and SJNNV will further elucidate the differences between these two NNV strains.

It will be important to carefully monitor the spread of VNN in Taiwan because this disease always results in very high mortality rates in the larval and juvenile stages of marine fish and causes severe economic losses at fish hatcheries. In this paper, we have reported the existence of viral nervous necrosis disease in cultured fish in Taiwan and
(C) 1997

Blackwell Science Ltd 
propose that screening for the VNN virus infection at all hatcheries and in different developmental stages of cultured grouper should be undertaken immediately in order to prevent the further spread of this disease.

\section{Acknowledgments}

This work was supported by the Council of Agriculture under grant No. 85-AST-1.13-FID06(16) and by the National Science Council under grant NSC 86-2311-B-002-048.

\section{References}

Awang A.B. (1987) Sea bass (Lates calcarifer) larvae and fry production in Malaysia. In: Management of Wild and Cultured Sea Bass Barramundi, Lates calcarifer (ed. by J.W. Copland \& D.L. Grey), pp. 144-147. Australian Center for International Agriculture Research, Canberra.

Bloch B., Gravningen K. \& Larsen J.L. (1991) Encephalomyelitis among turbot associated with a picornavirus-like agent. Diseases of Aquatic Organisms 10, 65-70.

Breuil G., Bonami J.R., Pepin J.F. \& Pichot Y. (1991) Viral infection (picorna-like) associated with mass mortalities in hatchery-reared sea bass Dicentrarchus labrax larvae and juveniles. Aquaculture 97, 109-116.

Glazon S. \& Charpentier G. (1991) Nodaviridae. In: Atlas of Invertebrate Viruses (ed. by J.R. Adames \& J.R. Bonami), p. 356. CRC Press, Boca Raton, FL.

Glazebrook J.S., Haesman M.P. \& de Beer S.W. (1990) Picornalike viral particles associated with mass mortalities in larval barramundi, Lates calcarifer Bloch. Journal of Fish Diseases 13, 245-249.

Mori K., Nakai T., Muroga K., Arimoto M., Mushiakc K. \& Furusawa I. (1992) Properties of a new virus belonging to Nodaviridae found in larval striped jack (Pseudocaranx dentex) with nervous necrosis. Virology 187, 368-371.

Mori K., Nakai T., Nagahara M., Muroga K., Mckuchi T. \& Kanno T. (1991) A viral disease in hatchery-reared larvae and juveniles of redspotted grouper. Gyobyo Kenkyu 26, 209-210.

Munday B.L., Langdon J.S., Hyatt A. \& Humphrey J.D. (1992) Mass mortality associated with a viral induced vacuolating encephalopathy and retinopathy of larval and juvenile barramundi, Lates calcarifer Bloch. Aquaculture 103, 197211.

Nishizawa T., Mori K., Nakai T., Furusawa I. \& Muroga K. (1994) Polymerase chain reaction amplification of RNA of striped jack nervous necrosis virus (SJNNV). Diseases of Aquatic Organisms 18, 103-107.

Nishizawa T., Mori K., Nakai T., Furusawa I. \& Muroga K. (1995) Comparison of the coat protein genes of five nodaviruses, the causative agents of viral nervous necrosis in marine fish. Journal of General Virology 76, 1563-1569.

Renault T., Haffner P., Baudin Laurencin F., Breuil G. \& Bonami J.R. (1991) Mass mortalities in hatchery-reared sea bass Lates calcarifer larvae associated with the presence in the brain and retina of virus-like particles. Bulletin of the European Association of Fish Pathologists 11, 68-73.

Strauss W.M. (1994) Preparation of genomic DNA from mammalian tissue. In: Current Protocols in Molecular Biology, Vol. 1 (ed. by F.M. Ausubel et al.), pp. 2.2.1-2.2.2. Green Publishers Association and Wiley-Interscience, New York, NY.

Yoshikoshi K. \& Inoue K. (1990) Viral nervous necrosis in hatchery-reared larvae and juveniles of Japanese parrotfish, Oplegnathus fasciatus (Temminck \& Schlegel). Journal of Fish Diseases 13, 69-77. 